\title{
Impact of a Hypothetical Infectious Disease Outbreak on US Exports and Export-Based Jobs
}

\author{
Zoe Bambery, Cynthia H. Cassell, Rebecca E. Bunnell, Kakoli Roy, \\ Zara Ahmed, Rebecca L. Payne, and Martin I. Meltzer
}

We estimated the impact on the US export economy of an illustrative infectious disease outbreak scenario in Southeast Asia that has 3 stages starting in 1 country and, if uncontained, spreads to 9 countries. We used 2014-2016 West Africa Ebola epidemic-related World Bank estimates of 3.3\% and 16.1\% reductions in gross domestic product (GDP). We also used US Department of Commerce job data to calculate export-related jobs at risk to any outbreak-related disruption in US exports. Assuming a direct correlation between GDP reductions and reduced demand for US exports, we estimated that the illustrative outbreak would cost from approximately $\$ 13$ million to approximately $\$ 64$ million (1 country) to $\$ 8$ billion to $\$ 41$ billion (9 countries) and place 1,500 to almost 1.4 million export-related US jobs at risk. Our analysis illustrates how global health security is enhanced, and the US economy is protected, when public health threats are rapidly detected and contained at their source.

Keywords: Global health security, Outbreaks, Economics, Exports, Jobs

$T$ he 2014-2016 West Africa Ebola epidemic exposed gaps in the global emergency response network, demonstrating that a disease threat, regardless of its location, can compromise global health security, including health security in the United States. ${ }^{1}$ The Ebola epidemic in West Africa caused 28,616 suspected, probable, and confirmed cases and 11,310 deaths. ${ }^{2}$ The World Bank es- timated that the overall economic impact of the Ebola crisis on Guinea, Liberia, and Sierra Leone was approximately $\$ 2.8$ billion ( $\$ 600$ million for Guinea, $\$ 300$ million for Liberia, and $\$ 1.9$ billion for Sierra Leone). This impact includes the economic shocks in 2014 and 2015 and the projections for 2016. The economic impact outlasted the epidemiologic impact. ${ }^{3}$

Zoe Bambery, MPP, is a Public Health Analyst; Cynthia H. Cassell, PhD, is Acting Associate Director for Applied Research and Evaluation; Rebecca E. Bunnell, ScD, is Deputy Director for Science, Policy and Communications; and Zara Ahmed, MPH, MPP, is Associate Director for Policy; all in the Office of the Director, Division of Global Health Protection, Center for Global Health, Centers for Disease Control and Prevention (CDC), Atlanta, GA. Kakoli Roy, PhD, is Senior Economist, Office of the Associate Director for Policy, Office of the Director; Rebecca L. Payne, MPH, is Associate Director for Policy, Communication and Strategy, Division of Adolescent and School Health, National Center for HIV/AIDS, Viral Hepatitis, and TB Prevention; and Martin I. Meltzer, MS, PhD, is Lead, Health Economics and Modeling Unit, Division of Preparedness and Emerging Infections, National Center for Emerging and Zoonotic Infectious Diseases; all at CDC, Atlanta, GA.

(C) Zoe Bambery et al., 2018; Published by Mary Ann Liebert, Inc. This Open Access article is distributed under the terms of the Creative Commons Attribution Noncommercial License (http://creativecommons.org/licenses/by-nc/4.0/) which permits any noncommercial use, distribution, and reproduction in any medium, provided the original author(s) and the source are credited. 
We cannot consider West Africa's Ebola epidemic an unlikely-to-be-repeated event. The risk of pandemic events is a constant, if not increasing, threat. ${ }^{1}$ Illustrating the economic risks associated with pandemics, the Commission on a Global Health Risk Framework for the Future determined that a conservatively low estimate of the annual economic costs of a global pandemic comparable to that of the 20th century influenza pandemics (ie, 1918 Spanish flu [H1N1], 1957 Asian flu [H2N2], or 1968 Hong Kong flu [H3N2]) would be approximately $\$ 64$ billion, with a $10 \%$ chance of the losses reaching $\$ 120$ billion per year. ${ }^{1}$ Such reductions in economic activity are likely to reduce the demand for imported goods and services in the affected countries. Thus, the economic problems triggered by a large-scale outbreak in 1 country can have adverse impacts on the export economies of other countries. ${ }^{1}$

In 2015, the estimated value of all US exports was approximately $\$ 2.2$ trillion, representing $13 \%$ of US gross domestic product (GDP). These exports supported approximately 11.5 million US jobs, or $8 \%$ of all US employment. ${ }^{4-6}$ Consequently, even if an outbreak of an infectious disease does not reach the United States, an outbreak in a foreign country or region could cause a disruption in the US export economy worth several hundred million dollars and jeopardize tens of thousands of US export-related jobs.

In this article, we present an illustrative scenario in which an infectious disease outbreak spreads in 3 stages across 9 contiguous countries. The resultant estimated risk-ofimpact to the US export market and US export-dependent jobs may help policymakers design and implement appropriately scaled programs to reduce the threat of infectious disease outbreaks and pandemics that could adversely affect US exports and jobs.

\section{Methods}

\section{Overview: Illustrative Outbreak Scenario}

Our illustrative outbreak scenario contains 3 stages of (an uncontained) spread of a hypothetical infectious pathogen/ disease in the Southeast Asia region. The 3 stages range from Stage I, when the outbreak is in the country where it is first identified; to Stage II, in which it spreads to an additional 5 countries; and then to Stage III, where the pathogen/disease spreads to a further 3 countries, for a total of 9 countries (Table 1). Breaking the scenario into 3 stages provides a clear illustration of the cost (in terms of risk to the US export economy) of failing to stop the spread of such an infectious disease outbreak.

For this illustration, we have not specifically defined the causative pathogen, as a number of potential candidates exist, such as avian influenza (eg, H5N1 or H7N9 strains), severe acute respiratory syndrome (SARS), or Middle East respiratory syndrome (MERS). It can be rationally assumed that there is a risk that such pathogens can evolve and adapt to allow sustained human-to-human transmission in the 9 countries (Table 1). Instead of focusing on the spread of the causative pathogen, we evaluated the spread of the economic impact that such an outbreak may generate, estimated in terms of reductions in GDP, and thus reductions in demand for US exports.

Table 1. Illustrative Scenario, by Stages of Spread, of a Hypothetical Infectious Disease Outbreak

\begin{tabular}{|c|c|c|c|}
\hline \multirow[b]{2}{*}{ Countries Affected ${ }^{\mathrm{a}}$} & \multicolumn{3}{|c|}{ Extent of Outbreak Prior to Containment ${ }^{\mathrm{b}}$} \\
\hline & Stage I & Stage II & Stage III \\
\hline Cambodia & $\begin{array}{l}\text { Outbreaks are identified } \\
\text { throughout the country. }\end{array}$ & \multirow{6}{*}{$\begin{array}{l}\text { Disease spreads across } \\
\text { international borders. } \\
\text { Outbreaks are now } \\
\text { identified in } 6 \text { countries in } \\
\text { Southeast Asia. }\end{array}$} & \multirow{9}{*}{$\begin{array}{l}\text { The disease continues to spread across } \\
\text { Southeast Asia. Outbreaks are } \\
\text { identified in } 3 \text { additional countries } \\
\text { (India, Pakistan, and China) before } \\
\text { it can be contained, controlled, and } \\
\text { eliminated from the } 9 \text { countries in } \\
\text { this region. }\end{array}$} \\
\hline Laos & & & \\
\hline Vietnam & & & \\
\hline Thailand & & & \\
\hline Malaysia & & & \\
\hline Indonesia & & & \\
\hline India & & & \\
\hline Pakistan & & & \\
\hline China & & & \\
\hline
\end{tabular}

${ }^{a}$ The illustrative scenario incorporates economic data from 9 contiguous countries (Table 2, Appendix Table 2) to illustrate how the spread of an infectious pathogen could potentially affect the US export economy. Scenario inputs were informed by the recent West Africa Ebola outbreak and associated economic modeling or other relevant evidence published by the World Bank (Table 2).

${ }^{\mathrm{b}}$ The unknown variables in the hypothetical scenario that affect the likelihood of an outbreak, including a pandemic, occurring at any point in time include: (1) the rate at which new infections or diseases emerge, and (2) the chance that those same diseases spread and evolve into more serious outbreaks. 
We selected Southeast Asia to illustrate the potential impact of a hypothetical outbreak because the region has been identified as having some of the largest relative risks for having an emerging infectious disease event (an outbreak) due to either zoonotic pathogens emerging from wildlife (and subsequent adaptation for sustained transmission in humans), drug-resistant pathogens, or vectorborne pathogens. ${ }^{1,7,8}$ Further, exports to Southeast Asia support the largest number of US export-related jobs. ${ }^{9}$ A large-scale infectious disease outbreak in Southeast Asia therefore presents one of the biggest risks of significantly disrupting the US export economy. ${ }^{10}$

\section{Estimating the Economic Impact}

To calculate the potential economic impacts of an outbreak in the countries in our scenario, we used an upper (16.3\%) and a lower estimate $(3.3 \%)$ of outbreak-related percentage reductions in GDP. The upper estimate was derived from the 2016 World Bank report that provides estimates of the economic impact on the 3 West African countries (Liberia, Sierra Leone, Guinea) that experienced the majority of Ebola cases $^{3,11}$ (Table 2). We derived this percentage decline in GDP by using as a numerator the estimated outbreak-related GDP dollar loss of $\$ 2.2$ billion in 2015 (approximately 1 year after the onset of the Ebola outbreak in West Africa) (Table 2). As the denominator, we used a GDP value of $\$ 13.5$ billion, totaled for all 3 countries (Table 2). This latter value is the estimated GDP for those 3 countries if the Ebola outbreak had not occurred. Per country values for these estimates are provided in Table 2. These declines in GDP were not even across all sectors of the affected countries. For example, the biggest Ebola-related declines in Liberia were seen in agriculture, mining, and services. Each of these sectors experienced more than 50\% reduction in GDP growth, and together they accounted for approximately $95 \%$ reduction in GDP (Appendix Table 1, supplementary material: http://online.liebertpub.com/doi/suppl/10.1089/hs .2017.0052).

As a lower estimate of economic impact, we used an outbreak-related 3.3\% reduction in GDP. We derived this estimate from a 2014 World Bank mathematical model. This model was used to estimate the "spillover" economic impact of Ebola epidemic to all 17 West African countries (Benin, Burkina Faso, Cape Verde, Cameroon, Cote D'Ivoire, The Gambia, Ghana, Guinea, Guinea-Bissau, Liberia, Mali, Mauritania, Niger, Nigeria, Senegal, Sierra Leone, and Togo) ${ }^{12}$ (Table 2). The complex World Bank model of the economic impact is based on estimates of Ebola epidemic-induced changes in demand and production in 6 sectors (agriculture, natural resources, trade, manufacturing, transport, and services) in each country. The World Bank report provided results from a number of models, which were built using a variety of assumptions. We used the results from the World Bank model labeled by those authors as "High Ebola scenario." In this World Bank model, it was assumed that the West African Ebola epidemic would eventually cause approximately 200,000 cases. ${ }^{12}$ This assumption is almost 10 -fold greater than what actually occurred in the West African Ebola epidemic. $^{2}$ In our illustrative outbreak scenario, however, we assume that the greatest impact occurs from an initially

Table 2. Inputs for Illustrative Scenario, by Country and Region

\begin{tabular}{|l|c|c|c|}
\hline Country or Region & $\begin{array}{c}\text { Lost GDP due to } \\
\text { Ebola Epidemic } \\
\text { (USD billion) }\end{array}$ & $\begin{array}{c}\text { Expected GDP per year, } \\
\text { Without Ebola } \\
\text { (USD billion) }\end{array}$ & $\begin{array}{c}\text { Impact of Ebola: } \\
\text { Percentage Loss } \\
\text { in GDP }\end{array}$ \\
\hline $\begin{array}{l}\text { Three primary } \\
\text { Ebola-affected countries } \\
\text { (combined total) }\end{array}$ & $\$ 2.2^{\mathrm{a}}$ & $\$ 13.5^{\mathrm{b}}$ & $16.3 \%$ \\
\hline Sierra Leone & $\$ 1.4^{\mathrm{a}}$ & $\$ 5.0^{\mathrm{b}}$ & $28.0 \%$ \\
\hline Guinea & $\$ 0.540^{\mathrm{a}}$ & $\$ 6.2^{\mathrm{b}}$ & $8.7 \%$ \\
\hline Liberia & $\$ 0.24^{\mathrm{a}}$ & $\$ 2.3^{\mathrm{b}}$ & $10.4 \%$ \\
\hline West Africa & $\$ 26.6^{\mathrm{d}}$ & $\$ 805.2^{\mathrm{b}}$ & $3.3 \%$ \\
\hline
\end{tabular}

Note: GDP = gross domestic product; USD = US dollars, in 2013 USD.

${ }^{a}$ Estimated values of economic impact, in terms of GDP loss over the course of a year due to Ebola in the 3 primary affected countries, are from the World Bank January 2015 report. ${ }^{11}$

${ }^{b}$ Estimates of expected GDP values, without the impact of Ebola, are based on pre-Ebola GDP estimates made in 2014. For the 3 primary Ebola-affected countries (Liberia, Sierra Leone, Guinea), this pre-Ebola GDP estimate is reported in the World Bank January 2015 report. ${ }^{11}$ For all of West Africa, the GDP estimate is reported in the World Bank October 2014 report. ${ }^{12}$

'The World Bank defines West Africa as including Benin, Burkina Faso, Cape Verde, Cameroon, Cote d'Ivoire, The Gambia, Ghana, Guinea, Guinea-Bissau, Liberia, Mali, Mauritania, Niger, Nigeria, Senegal, Sierra Leone, and Togo. ${ }^{12}$

${ }^{\mathrm{d}}$ The estimated GDP loss of $\$ 26.6$ billion (in 2013 USD) includes \$25.2 billion in GDP loss estimated for West Africa as reported in the World Bank October 2014 report, ${ }^{12}$ which estimates the foregone economic output attributable to Ebola's impact during a full year in the "High Ebola" scenario (see main text for further details).

${ }^{\mathrm{e}}$ Percentage loss is calculated using the 1-year (2015) estimated lost GDP due to Ebola (ie, the numerator) as a percentage of the expected 2015 GDP without Ebola (ie, the denominator). In the illustrative outbreak scenario in this article, the lower estimate of economic impact used was 3.3\% of GDP, and the upper limit was $16.3 \%$ of GDP. 
uncontained outbreak that causes cases in 9 countries (Table 1). These countries contain more than 2.5 billion people, with many living in urban areas with very high population densities. ${ }^{13}$ Under our assumptions, it is not necessarily unrealistic to assume that an initially uncontained outbreak that spreads to all 9 scenario countries would cause more than 100,000 cases.

In comparison, Lee and McKibbin estimated the global impact of the 2002-03 SARS epidemic. ${ }^{14}$ They calculated that the losses in Hong Kong were equivalent to $2.63 \%$ of GDP, and the reminder of China lost $1.05 \%$ of GDP. SARS was an epidemic that generated a global total in 37 countries of approximately 8,100 cases and 750 deaths ${ }^{15}$ far smaller in scope (cases and deaths), and approximately half the duration, of the West African Ebola epidemic used for our illustrative outbreak scenario.

For estimates of impact due to larger epidemics, McKibbin and Sidorenko ${ }^{16}$ produced a wide range of estimates of economic impact for influenza pandemics of differing severity. These estimates ranged from approximately $1 \%$ for a "mild" pandemic (1968-like) to an average of approximately $8.3 \%$ for a "severe" pandemic (1918-like). The country-specific estimates of GDP losses for the latter scenario included $9.2 \%$ for Indonesia, $19.3 \%$ for the Philippines, and $26.8 \%$ for Hong Kong. These country-specific estimates are similar to the Ebola-related impact on GDP measured in West Africa (Table 2).

\section{Estimating the Impact on US Export Economy}

To estimate the impact on the US export economy of a $3.3 \%$ to $16.3 \% 1$-year reduction in the GDP of the 9 countries affected in the illustrative scenario, we assumed a 1-to-1 correlation between reduction in GDP of importing countries and value of US exports to those countries. That is, we assumed a $3.3 \%$ or $16.3 \%$ reduction in the GDP of an importing country will result in a $3.3 \%$ to $16.3 \%$ reduction in US exports to that country. Thus, to calculate the potential loss of exports, we multiplied the 2015 recorded value of exports to each of the countries in the illustrative outbreak scenario by either 3.3\% or 16.3\% countries (see Appendix Table 2).

Although this is a simple extrapolation, it is not necessarily simplistic. Both the $3.3 \%$ and $16.3 \%$ estimates of reduction in GDP, for example, were generated from complex and sophisticated economic models that also assess the "spillover" effects associated with a sustained epidemic in neighboring countries. Those models take into account a large number of variables, including the interconnections between sectors of an economy and the trade between countries. ${ }^{12}$

The positive correlations between trade (both exports and imports) and growth in GDP is well known. The World Bank concluded that there is sufficient evidence to state that "... a rising share of world trade in GDP has been accompanied by rising per capita GDP since 1980." 17 (p60)

Figure 1. Estimated Range of Potential Values of Lost US Exports by Stages of Illustrative Outbreak Scenario ${ }^{1,2}$

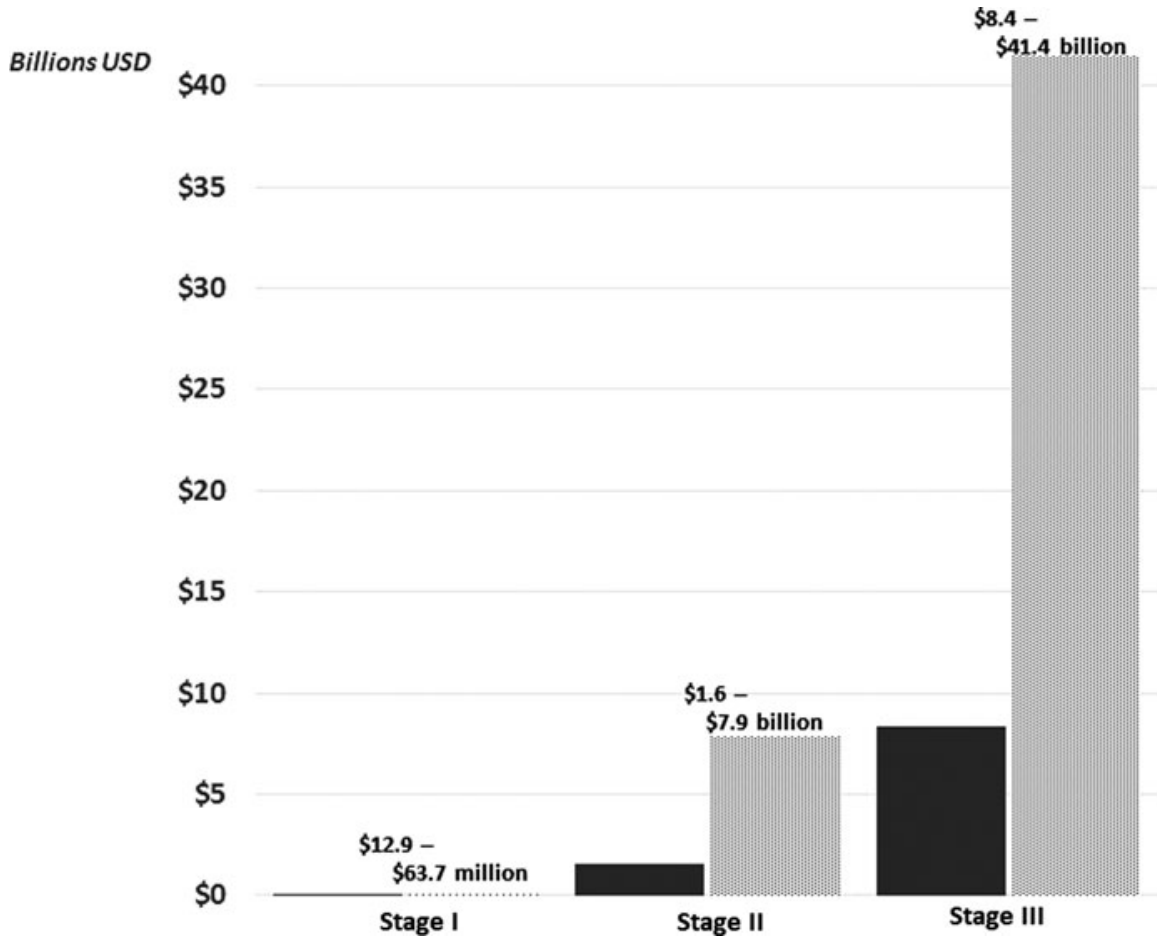

Low-end estimate for lost value of U.S. exports in staged scenario ( $3.3 \%$ reduction)

$\square$ High-end estimate for lost value of U.S. exports in staged scenario (16.3\% reduction)

Note: USD=US dollar. The 3 stages depicted here assume the outbreak spreads and is not contained to 1 country (for list of countries in each stage, see Table 1). It assumes a 1-to-1 correlation between the outbreak-related reduction in gross domestic product (GDP) and the reduction in demand for US exports (see Table 2 and Appendix Table 2). 
Obviously, there is a great deal of variability from country to country and, over time, in the correlation between economic growth and trade. Assuming a lower impact of an infectious disease outbreak is, in our model, equivalent to assuming a less than 1-to-1 correlation between GDP and trade (see sensitivity analysis below).

\section{Estimating the Value of US Exports at Risk}

To estimate the value of US exports and the number of jobs supported by those exports to the 9 countries, we used the export data, stratified by sectors, from the US Department of Commerce, International Trade Administration, and the Bureau of Economic Analysis. ${ }^{18-20}$ For comparison, we estimated the value of US exports and number of jobs supported by exports to the 9 affected countries as a share of total global US exports and export-dependent jobs, respectively. ${ }^{18-20}$

\section{Sensitivity Analysis}

We examined the impact of using a lower estimate of $2 \%$ loss of GDP due to an infectious disease outbreak, equivalent to the estimated impact of a "moderate" (1958-like) influenza pandemic. ${ }^{16}$

\section{REsults}

We estimate losses of US exports associated with Stage I of the illustrative outbreak scenario (outbreak occurring only in Cambodia) to range from US\$12.9 million to US\$63.7 million and to place 1,491 export-related US jobs at risk (Figures 1 and 2). If the illustrative outbreak were to expand to all 9 countries in the illustrative outbreak scenario (Stage III), the potential lost value of US exports would increase to a range of US $\$ 8.4$ billion to US $\$ 41.4$ billion, with almost 1.4 million export-related US jobs at risk (Figures 1 and 2).

\section{Sensitivity Analysis}

Using a $2 \%$ reduction in GDP due to an infectious disease outbreak resulted in estimated lost exports to Cambodia to $\$ 7.8$ million (Appendix, Table 2). If the illustrative outbreak were to expand to all 9 countries in the illustrative outbreak scenario (Stage III), the potential lost value of US exports would increase to $\$ 5.8$ billion (Appendix, Table 2 ).

\section{Discussion}

Our illustrative outbreak scenario shows the cost to the US export economy of a single country outbreak and the

Figure 2. Number of US Export-Related Jobs at Risk due to Illustrative Outbreak Scenario, by Stages ${ }^{1-3}$

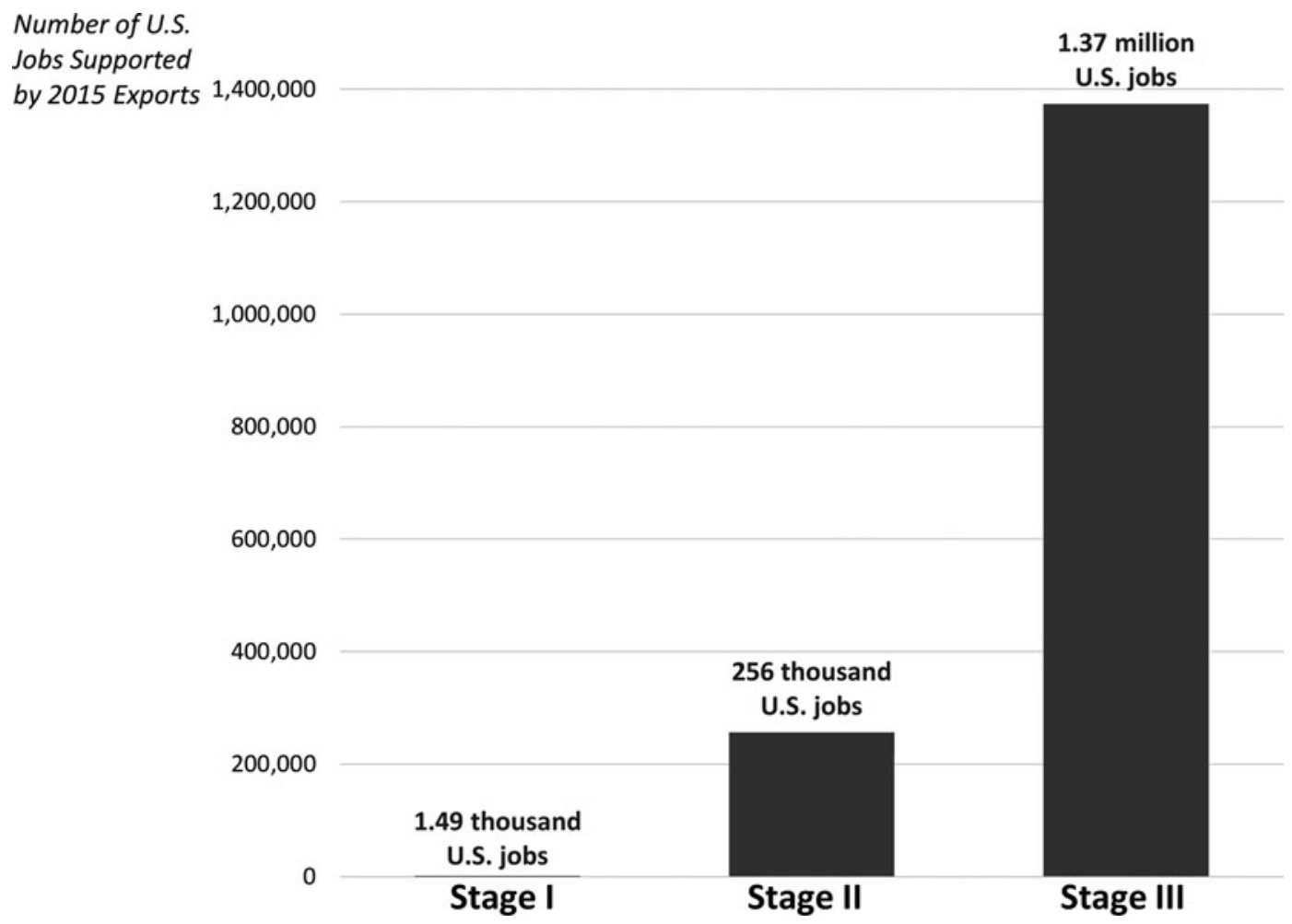

Note: Number of US jobs estimated number of jobs supported by US 2015 exports to countries included in illustrative outbreak scenario, where stages correspond to the degree that the outbreak is not contained to 1 country and the countries directly affected (Table 1). Categories listed on the horizontal axis depict the following countries and the stages of the outbreak: Stage I: Cambodia; Stage II: Cambodia, Laos, Vietnam, Thailand, Malaysia, and Indonesia; Stage III: Cambodia, Laos, Vietnam, Thailand, Malaysia, Indonesia, India, Pakistan, and China (Table 1). Assumes a 1-to-1 correlation between the reduction in demand for US exports and the epidemic-related reduction in gross domestic product (GDP) (see Table 2 and Appendix Table 2). 
exponential increases in costs if the outbreak escalates from 1 country (Stage I), a maximum cost of $\$ 63.7$ million, to a maximum cost of $\$ 41.4$ billion if the outbreak spreads to 9 countries (Stage III). The number of export-related US jobs at risk also rapidly rises as the illustrative outbreak spreads, from approximately 1,400 jobs at risk (Stage I) to more than 1.3 million jobs at risk (Stage III). The exact number of jobs that would be lost is likely to be very situation-specific.

Our estimates of potential economic impact are conservatively low when compared to other published estimates of the possible impact of infectious disease epidemics. ${ }^{14,15,20}$ For example, when examining the potential macro-economic impact of an avian influenza epidemic in 9 Southeast Asia countries, Bloom and colleagues estimated that an epidemic that caused 2 quarters ( 6 months) of economic contraction would result in a US\$99 billion reduction in demand side growth, plus a US $\$ 14$ billion reduction in supply (production) growth. ${ }^{21}$ An epidemic that lasted a full year (ie, similar to our illustrative scenario) would cause approximately US $\$ 283$ billion reduction in demand and a US\$14 billion reduction in supply. ${ }^{21}$ The latter estimates of the losses due to a year-long epidemic are equivalent to approximately a $6.8 \%$ reduction in GDP across all 9 countries (6.5\% due to reduced demand, $0.3 \%$ due to reduced supply). Further, our maximum estimate of losses is less than $5.0 \%$ of all US exports to countries by the global health security priority countries. ${ }^{9}$

One of the most important limitations to our illustrative outbreak scenario is the use of the estimates of the loss of GDP in West Africa due to Ebola. As we discussed earlier, however, the estimates of percentage loss of GDP in West Africa are not that different from other estimates of impact of epidemics in Southeast Asia. Perhaps harder to directly defend is our assumption of a direct 1-to-1 correlation between loss of GDP in countries importing US goods and reduction in US exports to the affected countries. As discussed earlier, there is sufficient evidence to reasonably assume a positive correlation between trade and growth in GDP. ${ }^{18}$

Further, we have not included in our analyses potential secondary economic effects that may be associated with the overall slowdown in an economy due to an infectious disease outbreak. For example, an infectious disease outbreak in Southeast Asia could slow, or even stop, the supply of essential components and inputs into US production systems and the economy, further aggravating the negative economic impact on the United States. But our point is not to generate a "precise estimate" of potential loss. Rather, our intent is to provide policymakers with an order-ofmagnitude of possible losses and also provide an estimate of the reduction in US exports and jobs at risk. Even if, for example, our estimates were reduced by $50 \%$, the impact on the US export economy of an uncontained outbreak in 9 countries would be considerable.

The results from this illustrative outbreak scenario clearly demonstrate that there is value in investing in systems that can (1) notably increase the probability of early detection of an outbreak of an infectious disease, and (2) ensure a rapid and effective response that successfully contains the outbreak before it spreads to other countries. SARS, MERS, H5N1 avian influenza, H7N9 avian influenza, the 2009 H1N1 influenza pandemic, the West African Ebola epidemic, and the current Zika epidemic all clearly illustrate that the risk of an outbreak of infectious disease is not confined to a handful of countries. The US Centers for Disease Control and Prevention (CDC) works with partners and in global health security priority countries to mitigate the threats posed by potential epidemics and pandemics and help contain such threats at their source.

Our findings illustrate how global health security, which relies on the capacity of all countries to rapidly detect and control public health threats, is critical to the US economy. Our analysis provides data that policymakers can use when deciding on programs to improve the prevention, detection, and response to outbreaks around the world and thereby help enhance global health security.

\section{ACKNOWLEDGMENTS}

We greatly appreciate Chris Rasmussen, $\mathrm{PhD}$, from the US Department of Commerce, Washington, DC, for his comments and feedback on this project. We also thank, for assistance with figure preparation, Dianne Brodalski with the Division of Global Health Protection, US Centers for Disease Control and Prevention, Atlanta, GA. The findings and conclusions in this report are those of the authors and do not necessarily represent the official position of the Centers for Disease Control and Prevention. All authors contributed to this work as part of their regular assigned duties as US federal government employees. No author has financial ties or disclosures or conflicts of interest related to the topic, material, and conclusions presented in this article.

\section{REFERENCES}

1. El Turabi A, Saynisch P. Appendix C: modeling the economic threat of pandemics. In: Commission on a Global Health Risk Framework for the Future. The Neglected Dimension of Global Security: A Framework to Counter Infectious Disease Crises. Washington, DC: National Academies Press; 2016:111-114. https://nam.edu/wp-content/uploads/2016/ 01/Neglected-Dimension-of-Global-Security.pdf. Accessed November 15, 2017.

2. US Centers for Disease Control and Prevention. 2014 Ebola outbreak in West Africa: case counts. CDC website. January 20, 2016. http://www.cdc.gov/vhf/ebola/outbreaks/2014west-africa/case-counts.html. Accessed November 15, 2017.

3. World Bank. 2014-2015 West Africa Ebola crisis: impact update. Washington, DC: World Bank Group; May 10, 2016. http://pubdocs.worldbank.org/en/297531463677588074/EbolaEconomic-Impact-and-Lessons-Paper-short-version.pdf. Accessed November 15, 2017. 
4. Trade Promotion Coordinating Committee. Helping US Businesses Increase Global Sales to Support Local Jobs. National Export Strategy 2016. Washington, DC: Trade Promotion Coordinating Committee; 2016. https://www.trade.gov/ publications/pdfs/nes2016.pdf. Accessed November 15, 2017.

5. Rasmussen C. Jobs supported by exports 2015: an update. Washington, DC: US Department of Commerce, International Trade Administration; 2016. http://www.trade.gov/mas/ian/ build/groups/public/@tg_ian/documents/webcontent/tg_ian_ 005500.pdf. Accessed November 15, 2017.

6. Rasmussen C, Xu S. Jobs supported by export destination 2015. Washington, DC: US Department of Commerce, International Trade Administration; 2016. http://trade.gov/mas/ ian/build/groups/public/@tg_ian/documents/webcontent/tg ian_005508.pdf. Accessed November 15, 2017.

7. Jones K, Patel NG, Levy MA, et al. Global trends in emerging infectious diseases. Nature 2008;451(7181):990993.

8. Jonas OB. Background Paper: Pandemic Risk. Washington, DC: World Bank; 2013. https://openknowledge.worldbank. org/bitstream/handle/10986/16343/WDR14_bp_Pandemic_ Risk_Jonas.pdf?sequence $=1 \&$ isAllowed $=y$. Accessed November 15, 2017.

9. Cassell CH, Bambery Z, Roy K, et al. Relevance of global health security to the US export economy. Health Secur 2017;15(6):563-568.

10. Langton D. Avian flu pandemic: potential impact of trade disruptions. CRS Report RS22453. Washington, DC: Congressional Research Services; 2008. http://www.dtic.mil/ get-tr-doc/pdf?AD=ADA476111. Accessed November 15, 2017.

11. World Bank. The economic impact of Ebola on Sub-Saharan Africa: updated estimates for 2015. Washington, DC: World Bank Group; 2015. https://openknowledge.worldbank.org/ bitstream/handle/10986/21303/937210REVISED000Jan 02002015000FINAL.pdf? sequence $=1$ \&isAllowed $=y$. Accessed November 15, 2017.

12. World Bank. The Economic Impact of the 2014 Ebola Epidemic: Short and Medium Term Estimates for West Africa. Washington, DC: World Bank Group; 2014. http:// documents.worldbank.org/curated/en/524521468141287875/ pdf/912190WP0see0a00070385314B00PUBLIC0.pdf. Accessed November 15, 2017.

13. World Bank. Population ranking (2015): World Bank data. http://databank.worldbank.org/data/download/POP.pdf. Accessed November 15, 2017.

14. Lee JW, McKibbin WJ. Estimating the global economic costs of SARS. In: Knobler S, Mahmoud A, Lemon S, Mack
A, Sivitz L, Oberholtzer K, eds. Learning from SARS: Preparing for the Next Disease Outbreak: Workshop Summary. Washington, DC: National Academies Press; 2004:92-109.

15. Smith RD. Responding to global infectious disease outbreaks: lessons from SARS on the role of risk perception, communication and management. Soc Sci Med 2006;63(12): 3113-3123.

16. McKibbin WJ, Sidorenko AA. The global costs of an influenza pandemic. Milken Institute Review 2007;9(3):18-27.

17. World Trade Organization. World Trade Report 2014. Trade and Development: Recent Trends and the Role of the WTO. Geneva: WTO; 2014. https://www.wto.org/english/res_e/ booksp_e/world_trade_report14_e.pdf. Accessed November 15, 2017.

18. US Department of Commerce, International Trade Administration. Jobs supported by export destination (Excel data). http://www.trade.gov/mas/ian/employment/index.asp. Accessed November 15, 2017.

19. US Department of Commerce, Bureau of Economic Analysis. International data; international services. December 19, 2016. https://www.bea.gov/iTable/iTable.cfm?ReqID=62\& step $=1 \#$ reqid $=62 \&$ step $=9 \&$ isuri $=1 \& 6210=4$. Accessed November 15, 2017.

20. US Department of Commerce, International Trade Administration. Trade and industry analysis: Trade Policy Information System (TPIS database). http://tpis1.trade.gov/ cgi-bin/wtpis/prod/tpis.cgi. Accessed November 15, 2017.

21. Bloom E, de Wit V, Carangal-San Jose MJ. Potential economic impact of an Asian flu pandemic on Asia. Policy brief \#42. Manila, Philippines: Asian Development Bank Economic and Research Department; 2008.

Manuscript received June 22, 2017;

revision returned August 3, 2017;

accepted for publication August 18, 2017.

Address correspondence to: Martin I. Meltzer, MS, PhD Senior Health Economist \& Distinguished Consultant Lead, Health Economics and Modeling Unit (HEMU) CDC/NCEZID/DPEI Mailstop C-18 1600 Clifton Rd. Atlanta, GA 30329

Email: MMeltzer@cdc.gov 